НАУКОВИЙ ВІСНИК

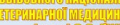

Sientific messenger of Liviv National University of

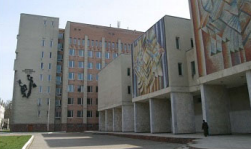

Том 22 № 100

2020

Науковий вісник Дьвівського національного університету ветеринарної медицини та біотехнологій імені С.3. Гжицького. Серія: Ветеринарні науки

\author{
Scientific Messenger of Lviv National University \\ of Veterinary Medicine and Biotechnologies. \\ Series: Veterinary sciences
}

UDC 619:612.12:615.9

\title{
The effect of sodium selenite and feed additive "Metisevit plus" on the protein- synthesizing function and functional state of the liver of rats under prolonged cadmium and lead loading
}

\author{
S. O. Slobodian ${ }^{1}$, B. V. Gutyj ${ }^{1}$, D. F. Gufriy ${ }^{1}$, P. S. Hnativ ${ }^{2}$, S. D. Murska ${ }^{3}$

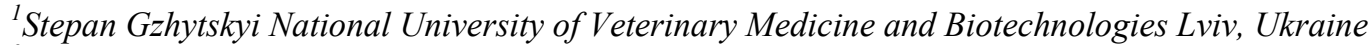 \\ ${ }^{2}$ Lviv National Agrarian University, Lviv, Ukraine \\ ${ }^{3}$ State scientific research control institute of veterinary preparations and feed additives, Lviv, Ukraine
}

Article info

Received 02.10.2020

Received in revised form 02.11 .2020

Accepted 03.11.2020

Stepan Gzhytskyi National University of Veterinary Medicine and Biotechnologies Lviv, Pekarska Str., 50, Lviv, 79010, Ukraine. Tel.: +38-067-316-74-30 E-mail:solomiaslobodian@ukr.net

Lviv National Agrarian University, Great Vladimir Str., 1, Dubliany, Zhovkva district, L'viv region, 80381, Ukraine.

State Scientific-Research Control Institute of Veterenary Medicinal Products and Feed Additives. Donetska Str., 11, Lviv, 79019, Ukraine.
Slobodian, S. O., Gutyj, B. V., Gufriy, D. F., Hnativ, P. S., \& Murska, S. D. (2020). The effect of sodium selenite and feed additive "Metisevit plus" on the protein-synthesizing function and functional state of the liver of rats under prolonged cadmium and lead loading. Scientific Messenger of Lviv National University of Veterinary Medicine and Biotechnologies. Series: Veterinary sciences, 22(100), 54-59. doi: 10.32718/nvlvet10010

In the conditions of modern technogenic pollution of the environment, environmental problems, improving the quality of livestock products and their food safety is an important and urgent issue today. Pollution of the environment with heavy metals due to man-made activities of the population has led to a number of problems of agricultural production. The aim of the study was to investigate the effect of sodium selenite and feed additive "Metisevit plus" on the protein-synthesizing function and functional state of the liver of rats in lead-cadmium intoxication. It was found that the level of total protein in the blood of rats exposed to cadmium and lead was reduced. These changes were due to a decrease in albumin levels and an increase in globulin levels. Thus, hypoproteinemia resulting from cadmium and lead poisoning may indicate impaired hepatic protein synthesis. Transamination enzymes play a major role in the relationship between protein and carbohydrate metabolism, which is important for switching the oxidation of energy substrates from glucose to amino acid energy nutrition, which is extremely important under the influence of various environmental factors. The most active transaminases are aspartate aminotransferase and alanine aminotransferase. In the study of the activity of aminotransferases in the serum of rats treated with lead acetate and cadmium chloride, an increase in the activity of enzymes in all periods of the study. The highest activity of aminotransferases was on days 21 and 28 of the experiment in the control group of rats, which carried out the combined load of cadmium and lead. Thus, the load of the body of animals with cadmium and lead contributes to the violation of the functional state and protein-synthesizing function of the liver of animals of the experimental groups. With the introduction of sodium selenite into the body of rats, the activity of ALT and AST in the serum of the first experimental group was slightly reduced compared with the control group. However, the activity of these enzymes did not reach physiological values. When setting the feed additive "Metisevit plus" throughout the experiment, it was found that the activity of aminotransferases in the serum of rats of the second experimental group ranged within physiological values. This is due to the hepatoprotective effect of the components of the feed additive "Metisevit Plus". In the study of proteinsynthesizing function of rat liver in experimental lead-cadmium toxicosis, it was found that after application to rats of the first experimental group of sodium selenite on days 14,21 and 28, the level of total protein in serum gradually increased, but did not reach physiological values. Using the feed supplement "Metisevit plus" rats of the second experimental group, found a slightly higher level of total protein in their blood, which on the 28th day of the experiment reached physiological values and, accordingly, amounted to $66.8 \pm 1.99 \mathrm{~g} / \mathrm{l}$. It should be noted that when administering the feed additive "Metisevit plus" proteinsynthesizing liver function and liver function of rats of the second experimental group were restored faster than when administering sodium selenite to the first experimental group.

Key words: pharmacology, toxicology, Cadmium, Lead, sodium selenite, Metisevit plus. 


\title{
Вплив селеніту натрію i кормової добавки "Метісевіт плюс" на протеїнсинтезувальну функцію та функціональний стан печінки щурів за тривалого кадмісвого та свинцевого навантаження
}

\author{
С. О. Слободян ${ }^{1}$, Б. В. Гутий ${ }^{1}$, Д. Ф. Гуфрій ${ }^{1}$, П. С. Гнатів ${ }^{2}$ С. Д. Мурська ${ }^{3}$ \\ ${ }^{1}$ Львівський національний університет ветеринарної медицини та біотехнологій імені С. 3. Гжицького, м. Львів, \\ Україна \\ ${ }^{2}$ Львівський національний аграрний університет, м. Львів, Украӥна \\ ${ }^{3}$ Державний науково-дослідний контрольний інститут ветеринарних препаратів та кормових добавок, \\ м. Львів, Украӥна
}

\begin{abstract}
В умовах сучасного техногенного забруднення навколишнього середовища екологічні проблеми, підвищення якості тваринницької продукції та ї̈ харчової безпеки є важливим і актуальним питанням сьогодення. Забруднення довкілля важкими металами внаслідок техногенної діяльності населення призвело до иілого ряду проблем сільськогосподарського виробництва. Метою роботи було дослідити вплив селеніту натрію і кормової добавки “Метісевіт плюс" на протеїнсинтезувальну функцію та функиіональний стан печінки щурів за свиниево-кадмієвої інтоксикації. Встановлено, що у крові щурів, яким здійснювали кадмієве і свинцеве навантаження рівень загального протеїну знижувався. Дані зміни проходили за рахунок зниження рівня альбумінів та зростання рівня глобулінів. Таким чином, гіпопротеїнемія, яка виникає внаслідок отруєння Кадмієм і Свинщем, може вказувати про порушення протеїнсинтезувальної функції печінки. Ензимам трансамінування належить головна роль у взаємозв'язку протеїнового та вуглеводного обмінів, що важливо для перемикання окиснення енергетичних субстратів з глюкозного на амінокислотне енергетичне живлення, яке має виняткове значення за впливу різних чинників середовища. Найбільш активними трансаміназами є аспартатамінотрансфераза та аланін-амінотрансфераза. При дослідженні активності амінотрансфераз у сироватиі крові щурів, яким задавали ацетат свинщю та хлорид кадмію встановлено підвищення активності ензимів у всі періоди дослідження. Найвищою активність амінотрансфераз була на 21 і 28 доби досліду у контрольної групи шурів, який здійснювали сукупне навантаження Кадмієм і Свинщем. Отже навантаження організму тварин Кадмієм і Свинцем сприяє порушенню функиіонального стану та протеїнсинтезувальної функції печінки тварин дослідних груп. При введенні в організм щурів селеніту натрію, активність АлАТ $i$ АсАТ у сироватиі крові першої дослідної групи дещо знижувалася порівняно з контрольною групою. Однак, активність даних ензимів не доходила до фізіологічних величин. При задаванні кормової добавки “Метісевіт плюс" протягом усього досліду встановлено, що активність амінотрансфераз у сироватиі крові щурів другої дослідної групи коливалася у межах фізіологічних величин. Це зумовлено гепатопротекторною дією складників кормової добавки “Метісевіт плюс". При дослідженні протеїнсинтезувальноі функиії печінки щурів за експериментального свинцево-кадмієвого токсикозу встановлено, щзо після застосування щурам першоі дослідної групи селеніту натрію на 14, 21 і 28 доби рівень загального протеїну у сироватиі крові поступово підвишувався, проте не досягав фізіологічних величин. Застосувавщи кормову добавку "Метісевіт плюс" щурам другої дослідної групи, встановлено дещо вищий у їх крові рівень загального протеїну, який на 28 добу досліду досягав фізіологічних величин $і$ відповідно становив 66,8 1,99 г/л. Варто зазначити, щео при задаванні кормової добавки “Метісевіт плюс" протеїнсинтезувальна функція печінки та функиіональний стан печінки щурів другої дослідної групи відновлювалися швидше, ніж при задаванні селеніту натрію першій дослідній групі.
\end{abstract}

Ключові слова: фармакологія, токсикологія, Кадмій, Свинещь, селеніт натрію, Метісевіт плюс.

Вступ

Серед факторів, що впливають на живі організми, важкі метали посідають особливе місце, оскільки вони є найбільш широко поширеними токсикантами для багатьох форм життя (López Alonso \& Benedit, 2002). 3 еколого токсикологічної точки зору, йони важких металів не зникають із біологічного кругообігу, їх токсичність не зменшується, а навпаки, по мірі збільшення концентрації - зростає. Вони мають високу кумулятивну спроможність, саме тому їх небезпека полягає в можливих віддалених наслідках, які можуть бути ініційовані або спровоковані опосередкованим впливом накопичення металів (Chalaia, 2013; Kuras \& Ersteniuk, 2019; Lavryshyn et al., 2019).

Сполуки Кадмію - одного $з$ важких металів, що широко використовуються в промисловості, належать до основних засмічувачів навколишнього середовища (Ali et al., 1986; Lavryshyn et al., 2018). Забруднення грунтового покриву даним важким металом є одним 3 найбільш небезпечних екологічних явищ, так як він нагромаджується в рослинах вище норми, навіть за слабкого забруднення грунту (Myslyva, 2013; Hutyi,
2015). Підвищення його кількості в грунтах обумовлено різними техногенними впливами. До їх числа відносяться підприємства, що виробляють фарби, антисептичні речовини, лужні акумулятори, а також здійснюють виплавку кольорових металів, переробку мідних, свинцевих i, особливо, цинкових руд (Lavryshyn \& Gutyj, 2019). Надходження металу в навколишнє середовище пов'язане і з сільськогосподарським виробництвом, зокрема із застосуванням фосфорних добрив (Marushko et al., 2010; Ostapyuk \& Gutyj, 2018; 2019).

При надходженні в організм тварин Кадмій спричиняє низку токсичних ефектів, впливаючи на різні органи і системи, у тому числі й на нирки та печінку (Al-Azemi et al., 2010). Навіть незначні концентрації Кадмію здатні викликати незворотні функціональні порушення, деформації, а іноді і загибель тварин (Gutyj et al., 2018).

Свинець є одним із найтоксичніших важких металів, який здатний блокувати реактивні (сульфгідрильні, карбоксильні та фосфатні) групи біополімерів, у тому числі білків, нуклеїнових кислот та ензимів (Chalaia, 2013; Slobodian et al., 2020). 
У науковій літературі повідомляється, що Свинець пошкоджує мембрани клітин, змінює їх проникність, знижує стійкість до осмотичного шоку, порушує біоенергетичні процеси в клітинах (Chen et al., 2019). Зокрема, сполуки Свинцю здатні пригнічувати неспецифічну резистентність і стійкість організму тварин до інфекцій та стимулювати автоімунні реакції (Petrynych et al., 2017).

При потраплянні великої кількості солей Свинцю в організм тварин, він має виражену мембрано токсичну дію, наслідком якої є активація згортання крові 3 утворенням тромбів та порушення мікроциркуляції внутрішніх органів (Myslyva, 2013; Stepanchuk, 2014). Характер розподілу Свинцю та ступінь його накопичення в організмі тварин залежить від спорідненості до різних структур та біохімічних компонентів тканин і органів, міцності утворених комплексів, швидкості їх елімінації (Slobodian et al., 2019).

Метою роботи було дослідити вплив селеніту натрію і кормової добавки “Метісевіт плюс" на протеїнсинтезувальну функцію та функціональний стан печінки щурів за свинцево-кадмієвої інтоксикації.

\section{Матеріал і методи досліджень}

Досліди проводились на щурах-самцях лінії "Вістар", масою 200-220 г, з яких було сформовано 3 групи тварин: контрольну та дві дослідні. Щурам контрольної та дослідних груп вводили 16,6 \% водний розчин ацетату свинцю в дозі 100 мг/кг і 0,029 \% водний розчин кадмію хлориду в дозі 2,0 мг/кг. Щурам першої дослідної групи (Д $)$ додатково застосовували селеніт натрію у дозі 0,2 мг/кг маси тіла. Щурам другої дослідної групи додатково застосовували кормову добавку “Метісевіт плюс” у дозі 0,5 мг/кг маси тіла.
Упродовж усього експерименту щурів утримували на збалансованому раціоні, що був збалансований за усіма необхідними компоненти, питну воду тварини отримували без обмежень із скляних поїлок об'ємом 0,2 літра.

Усі маніпуляції з тваринами проводили відповідно до Європейської конвенції про захист хребетних тварин, які використовуються для експериментальних $\mathrm{i}$ наукових цілей (Страсбург, 1986 р.).

Кров для біохімічних досліджень забирали під ефірним наркозом з яремної вени на 1, 7, 14, 21 та 28 доби досліду. Досліджували концентрацію протеїну, його фракцій, активність амінотрансфераз за методикою (Vlizlo, 2012).

Аналіз результатів досліджень проводили за допомогою пакету програм Statistica 6.0. Вірогідність різниць оцінювали за t-критерієм Стьюдента. Результати вважали вірогідними при $\mathrm{P} \leq 0,05$.

\section{Результати та їх обговорення}

Функціональний стан печінки щурів за впливу препаратів-антиоксидантів досліджували за визначенням у сироватці крові активності ензимів групи амінотрансфераз, зокрема, аспартат- і аланінамінотрансферази.

Як видно 3 даних, наведених у таблиці 1, активність аланін-амінотрансферази на початку досліду, була в межах фізіологічних величин. Після задавання солей Кадмію та Свинцю активність даного ензиму у сироватці крові щурів контрольної групи на 21 добу досліду підвищилася у два рази, де відповідно становила $110,23 \pm 6,16$ мкмоль/(л·год).

\section{Таблиця 1}

Вплив селеніту натрію та кормової добавки “Метісевіт плюс" на активність аланін-амінотрансферази у сироватці крові щурів за інтоксикації Кадмієм і Свинцем, мкмоль/(л·год) $(\mathrm{M} \pm \mathrm{m}, \mathrm{n}=6)$

\begin{tabular}{|c|c|c|c|c|c|}
\hline \multirow{2}{*}{ Групи тварин } & \multirow{2}{*}{ Вихідні дані } & \multicolumn{4}{|c|}{ доба експерименту } \\
\hline & & 7 & 14 & 21 & 28 \\
\hline Контрольна $\left(\mathrm{Cd}^{2+}+\mathrm{Pb}^{2+}\right)$ & $53,41 \pm 6,61$ & $67,42 \pm 2,39$ & $85,45 \pm 3,67$ & $110,23 \pm 6,16$ & $98,55 \pm 7,86$ \\
\hline $\begin{array}{l}\text { Дослідна } 1\left(\mathrm{Cd}^{2+}+\mathrm{Pb}^{2+}+\right. \\
\text { селеніт натрію) }\end{array}$ & $52,98 \pm 5,58$ & $64,23 \pm 4,33$ & $70,34 \pm 2,84 * *$ & $78,61 \pm 1,99 * * *$ & $67,81 \pm 5,62 * * *$ \\
\hline $\begin{array}{l}\text { Дослідна } 2\left(\mathrm{Cd}^{2+}+\mathrm{Pb}^{2+}+\right. \\
\text { Метісевіт плюс) }\end{array}$ & $53,50 \pm 4,98$ & $59,81 \pm 5,05$ & $60,47 \pm 3,87 * * *$ & $63,98 \pm 5,03 * * *$ & $57,41 \pm 3,95 * * *$ \\
\hline
\end{tabular}

Після застосування щурам першої дослідної групи селеніту натрію, активність АлАТ у їх сироватці крові коливалася у межах величин 64,23 \pm 4,33 - 78,61 \pm 1,99 мкмоль/(л·год). Найвищою активність була на 21 добу досліду, де вона порівняно з початковими величинами зросла на 48,4 \%. На 28 добу досліду активність ензиму була нижчою на 31,2 \% відносно показників щурів контрольної групи К.

При застосуванні кормової добавки "Метісевіт плюс" протягом усього досліду встановлено, що активність АлАТ у сироватці крові другої дослідної групи коливалася у межах фізіологічних величин, лише на 21 добу досліду встановлено підвищення активності даного ензиму на 19,6 \% порівняно з початковими величинами, взятими до задавання солей важких металів.

Активність аспартат-амінотрансферази у сироватці крові щурів за інтоксикації важкими металами наведена у таблиці 2. Встановлено, що активність ензиму у сироватці крові щурів групи К зростала протягом усього досліду. 


\section{Таблиця 2}

Вплив селеніту натрію та кормової добавки “Метісевіт плюс" на активність аспартат-амінотрансферази у сироватці крові щурів за інтоксикації Кадмієм і Свинцем, мкмоль/(л·год) $(\mathrm{M} \pm \mathrm{m}, \mathrm{n}=6)$

\begin{tabular}{|c|c|c|c|c|c|}
\hline \multirow{2}{*}{ Групи тварин } & \multirow{2}{*}{ Вихідні дані } & \multicolumn{4}{|c|}{ доба експерименту } \\
\hline & & 7 & 14 & 21 & 28 \\
\hline Контрольна $\left(\mathrm{Cd}^{2+}+\mathrm{Pb}^{2+}\right)$ & $146,6 \pm 15,1$ & $168,3 \pm 12,1$ & $187,6 \pm 11,4$ & $196,9 \pm 14,1$ & $190,2 \pm 10,6$ \\
\hline $\begin{array}{l}\text { Дослідна } 1\left(\mathrm{Cd}^{2+}+\mathrm{Pb}^{2+}+\right. \\
\text { селеніт натрію) }\end{array}$ & $144,9 \pm 13,6$ & $157,5 \pm 13,0$ & $166,2 \pm 10,9$ & $170,9 \pm 12,7$ & $172,2 \pm 11,9$ \\
\hline $\begin{array}{l}\text { Дослідна } 2\left(\mathrm{Cd}^{2+}+\mathrm{Pb}^{2+}+\right. \\
\text { Метісевіт плюс })\end{array}$ & $146,3 \pm 10,8$ & $150,1 \pm 12,7$ & $153,3 \pm 12,2 *$ & $159,1 \pm 15,0^{*}$ & $152,6 \pm 15,0 *$ \\
\hline
\end{tabular}

Найвищою активність АсАТ була на 21 і 28 добу досліду, де порівняно $з$ початковими величинами вона зросла на 34,3 і 29,7 \% відповідно. Таке збільшення активності амінотрасфераз у сироватці крові щурів вказує на порушення цілісності плазматичних мембран клітин печінки.

Після введення в організм щурів селеніту натрію, активність АсАТ у сироватці крові першої дослідної групи дещо знижувалася порівняно 3 контрольною групою. Однак, активність даного ензиму не доходила до фізіологічних величин, так при порівнянні з початковим даними активність АсАТ зросла на 21 добу досліду на 17,9 \% на 28 добу досліду - на 18,8 \%.
При застосуванні кормової добавки “Метісевіт плюс" щурам другої дослідної групи встановлено зниження активності АсАТ у їх крові на 7 добу досліду на $10,8 \%$, на 14 добу досліду - на 18,3\%, на 21 добу досліду - на 19,2 \% та на 28 добу - на 19,8 \%.

Отже, застосування кормової добавки "Метісевіт плюс" тваринам за умов кадмієвого і свинцевого навантаження, сприяло нормалізації активності амінотрансфераз.

Після дослідження протеїнсинтезувальної функції печінки у щурів контрольної та дослідних груп встановлено, що на початку досліду рівень загального протеїну у їх крові коливався у межах величин $65,3 \pm 1,68-66,1 \pm 1,95$ г/л (табл. 3 ).

\section{Таблиця 3}

Вплив селеніту натрію та кормової добавки “Метісевіт плюс" на рівень загального протеїну у крові щурів за інтоксикації Кадмієм і Свинцем, г/л $(\mathrm{M} \pm \mathrm{m}, \mathrm{n}=6)$

\begin{tabular}{lccccc}
\hline \multicolumn{1}{c}{ Групи тварин } & \multirow{2}{*}{ Вихідні дані } & \multicolumn{4}{c}{ доба експерименту } \\
\cline { 3 - 5 } & & 7 & 14 & 21 & 28 \\
\hline Контрольна $\left(\mathrm{Cd}^{2+}+\mathrm{Pb}^{2+}\right)$ & $65,3 \pm 1,68$ & $63,9 \pm 1,75$ & $59,6 \pm 2,00$ & $58,3 \pm 1,68$ & $59,1 \pm 2,37$ \\
Дослідна 1 $\left(\mathrm{Cd}^{2+}+\mathrm{Pb}^{2+}+\right.$ & $66,1 \pm 1,95$ & $65,3 \pm 2,14$ & $62,7 \pm 1,55$ & $61,6 \pm 1,78$ & $62,0 \pm 2,40$ \\
селеніт натрію) & $65,7 \pm 1,74$ & $65,4 \pm 1,95$ & $64,9 \pm 2,19$ & $65,2 \pm 2,11 *$ & $66,8 \pm 1,99 *$ \\
Дослідна 2 $\left(\mathrm{Cd}^{2+}+\mathrm{Pb}^{2+}+\right.$ & 650 Метісевіт плюс) &
\end{tabular}

За кадмієвого та свинцевого навантаження встановлено пригнічення протеїнсинтезувальної функції печінки щурів контрольної групи. Так, на 21 добу досліду рівень загального протеїну знизився на 10,7 \%, а на 28 добу досліду - на 9,5 \% відносно початкових даних.

При застосуванні селеніту натрію щурам першої дослідної групи за інтоксикації важкими металами встановлено, що рівень загального протеїну у їх крові на 14 добу досліду зріс на 5,2 \%, а на 21 добу - на 5,7 \%.

Після згодовування кормової добавки "Метісевіт плюс" щурам другої дослідної групи встановлено вірогідне зростання рівня загального протеїну на 14 i 21 доби досліду на 8,9 і 11,8 \% порівняно з показниками контрольної групи щурів. На 28 добу досліду рівень загального протеїну був найвищим у крові другої дослідної групи, де відповідно цей показник становив $66,8 \pm 1,99$ г/л.

Зниження загального протеїну у крові щурів, яким здійснювали навантаження важкими металами супроводжувалося зниженням рівня альбумінів, де відповідно на 21 і 28 добу досліду даний показник знизився на 25,1 і 23,3 \% відносно початкових величин (табл. 4).

\section{Таблиця 4}

Вплив селеніту натрію та кормової добавки “Метісевіт плюс" на рівень альбумінів у крові щурів за інтоксикації Кадмієм і Свинцем, г/л $(\mathrm{M} \pm \mathrm{m}, \mathrm{n}=6)$

\begin{tabular}{|c|c|c|c|c|c|}
\hline \multirow{2}{*}{ Групи тварин } & \multirow{2}{*}{ Вихідні дані } & \multicolumn{4}{|c|}{ доба експерименту } \\
\hline & & 7 & 14 & 21 & 28 \\
\hline Контрольна $\left(\mathrm{Cd}^{2+}+\mathrm{Pb}^{2+}\right)$ & $22,7 \pm 1,35$ & $19,9 \pm 2,05$ & $17,6 \pm 1,87$ & $17,0 \pm 1,61$ & $17,4 \pm 1,23$ \\
\hline $\begin{array}{l}\text { Дослідна } 1\left(\mathrm{Cd}^{2+}+\mathrm{Pb}^{2+}+\right. \\
\text { селеніт натрію) }\end{array}$ & $22,9 \pm 1,40$ & $21,6 \pm 2,12$ & $19,4 \pm 1,23$ & $19,0 \pm 2,04$ & $19,3 \pm 1,34$ \\
\hline $\begin{array}{l}\text { Дослідна } 2\left(\mathrm{Cd}^{2+}+\mathrm{Pb}^{2+}+\right. \\
\text { Метісевіт плюс })\end{array}$ & $22,4 \pm 1,29$ & $21,7 \pm 1,55$ & $21,4 \pm 1,86$ & $21,6 \pm 1,92 *$ & $22,2 \pm 2,00^{*}$ \\
\hline
\end{tabular}


Згодовування селеніту натрію та кормової добавки “Метісевіт плюс" щурам дослідних груп за інтоксикації згаданими вище важкими металами встановлено підвищення рівня альбумінів на 7 добу досліду на 8,5 і 9,0 \% відповідно. На 14 добу досліду рівень альбумінів відповідно зріс на 10,2 і 21,6 \%. На 21 добу дос- ліду найвищим рівень альбумінів був у крові щурів другої дослідної групи, де відповідно цей показник становив 21,6 \pm 1,92 г/л, тоді як у першої дослідної групи рівень альбумінів коливався у межах $19,0 \pm 2,04$ г/л.

\section{Таблиця 5}

Вплив селеніту натрію та кормової добавки “Метісевіт плюс" на рівень глобулінів у крові щурів за інтоксикації Кадмієм і Свинцем, г/л $(\mathrm{M} \pm \mathrm{m}, \mathrm{n}=6)$

\begin{tabular}{|c|c|c|c|c|c|}
\hline \multirow{2}{*}{ Групи тварин } & \multirow{2}{*}{ Вихідні дані } & \multicolumn{4}{|c|}{ доба експерименту } \\
\hline & & 7 & 14 & 21 & 28 \\
\hline Контрольна $\left(\mathrm{Cd}^{2+}+\mathrm{Pb}^{2+}\right)$ & $42,6 \pm 2,13$ & $44,0 \pm 2,24$ & $42,0 \pm 1,93$ & $41,3 \pm 2,02$ & $41,7 \pm 1,62$ \\
\hline $\begin{array}{l}\text { Дослідна } 1\left(\mathrm{Cd}^{2+}+\mathrm{Pb}^{2+}+\right. \\
\text { селеніт натрію) }\end{array}$ & $43,2 \pm 1,85$ & $43,7 \pm 2,44$ & $43,3 \pm 1,08$ & $42,6 \pm 1,56$ & $42,7 \pm 2,10$ \\
\hline $\begin{array}{l}\text { Дослідна } 2\left(\mathrm{Cd}^{2+}+\mathrm{Pb}^{2+}+\right. \\
\text { Метісевіт плюс })\end{array}$ & $43,3 \pm 1,28$ & $43,7 \pm 2,36$ & $43,5 \pm 2,02$ & $43,6 \pm 2,12$ & $44,6 \pm 1,23$ \\
\hline
\end{tabular}

На 28 добу досліду рівень альбумінів у крові першої дослідної групи зріс на 10,9%, у другої дослідної групи - на 29,3 \% відносно контрольної групи.

При дослідженні рівня глобулінів у крові щурів, яким здійснювали навантаження згаданими вище важкими металами та задавали селеніт натрію та кормову добавку "Метісевіт плюс" встановлено незначне підвищення рівня даного показника.

Варто зауважити, що при задаванні кормової добавки “Метісевіт плюс" протеїнсинтезувальна функція печінки щурів другої дослідної групи відновлювалася швидше, ніж при задаванні селеніту натрію першій дослідній групі.

\section{Висновки}

Свинцево-кадмієве навантаження у щурів сприяє порушенню функціонального стану (підвищення активності АлАТ і АсАТ) та протеїнсинтезувальної функції печінки (зниження рівня загального протеїну, альбумінів та глобулінів) тварин дослідних груп.

Селеніт натрію та кормова добавка "Метісевіт плюс" за експериментального свинцево-кадмієвого токсикозу у щурів сприяли поступовому відновленню протеїнсинтезувальної функції (підвищення рівня загального протеїну на 5,7 і 11,8 \%) та функціонального стану печінки (зниження активності аланінамінотрансферази на 31,2 i $41,7 \%$ та аспартатамінотрансферази - на 9,5 і 19,8 \%).

Згодовування з кормом кормової добавки "Метісевіт плюс" сприяло кращій нормалізуючій дії вказаних показників ніж застосування селеніту натрію.

\section{Подяка}

Ця робота була фінансово підтримана Міністерством освіти і науки України (0120U101999).

\section{References}

Al-Azemi, M., Omu, F. E., Kehinde, E. O., Anim, J. T., Oriowo, M. A., \& Omu, A. E. (2010). Lithium protects against toxic effects of cadmium in the rat testes.
J. Assist. Reprod. Genet, 27(8), 469-476. doi: 10.1007/s10815-010-9426-3.

Ali, M. M., Murthy, R. C., \& Chandra, S. V. (1986). Developmental and longterm neurobehavioral toxicity of low-level in utero $\mathrm{Cd}$ exposure in rats. Neurobehavioral Toxicology and Teratology, 8 (5), 463-468. URL: https://www.ncbi.nlm.nih.gov/pubmed/3785508.

Chalaia, O. S. (2013). Vplyv riznykh rivniv kadmiiu ta svyntsiu $\mathrm{v}$ ratsioni molodniaku svynei na produktyvnist i zabiini yakosti. Tavriiskyi naukovyi visnyk, 83, 196-202 (in Ukrainian).

Chen, Q. Y., DesMarais, T., \& Costa, M. (2019). Metals and Mechanisms of Carcinogenesis. Annual Review of Pharmacology and Toxicology, 59(1), 537-554. doi: 10.1146/annurev-pharmtox-010818-021031.

Gutyi, B., Ostapiuk, A., Kachmar, N., Stadnytska, O., Sobolev, O., Binkevych, V., Petryshak, R., Petryshak, O., Kulyaba, O., Naumyuk, A., Nedashkivsky, V., Nedashkivska, N., Magrelo, N., Golodyuk, I., Nazaruk, N., \& Binkevych, O. (2019). The effect of cadmium loading on protein synthesis function and functional state of laying hens' liver. Ukrainian Journal of Ecology, 9(3), 222-226. URL: https://www.ujecology.com/articles/ the-effect-of-cadmium-loading-on-protein-synthesisfunction-and-functional-state-of-laying-hens-liver.pdf.

Gutyj, B. V., Gufriy, D. F., Binkevych, V. Y., Vasiv, R. O., Demus, N. V., Leskiv, K. Y., Binkevych, O. M., \& Pavliv, O. V. (2018). Influence of cadmium loading on glutathione system of antioxidant protection of the bullocks'bodies. Scientific Messenger of Lviv National University of Veterinary Medicine and Biotechnologies. Series: Veterinary sciences, 20(92), 34-40. doi: $10.32718 /$ nvlvet9207.

Hutyi, B. V. (2015). Aktyvnist systemy antyoksydantnoho zakhystu orhanizmu bychkiv za hostroho kadmiievoho toksykozu. Naukovyi visnyk Lvivskoho natsionalnoho universytetu veterynarnoi medytsyny ta biotekhnolohii im. Gzhytskoho, 17, 1 (1), 31-36. URL: http://nbuv.gov.ua/UJRN/nvlnu_2015_17_1(1)_8 (in Ukrainian).

Kuras, L. D., \& Ersteniuk, H. M. (2019). Pokaznyky enerhetychnoho obminu v sertsevii tkanyni eksperymentalnykh tvaryn za umov vplyvu kadmii khlorydu. 
Medychna ta klinichna khimiia, 21 (1), 25-31. URL: http://nbuv.gov.ua/UJRN/Medkh $201921 \quad 16$ (in Ukrainian).

Lavryshyn, Y. Y., \& Gutyj, B. V. (2019). Protein synthesize function of bulls liver at experimental chronic cadmium toxicity. Scientific Messenger of Lviv National University of Veterinary Medicine and Biotechnologies. Series: Veterinary sciences, 21(94), 92-96. doi: $10.32718 /$ nvlvet9417.

Lavryshyn, Y. Y., Gutyj, B. V., Palyadichuk, O. R., \& Vishchur, V. Y. (2018). Morphological blood indices of bulls in experimental chronic cadmium toxicosis. Scientific Messenger of Lviv National University of Veterinary Medicine and Biotechnologies. Series: Veterinary 20(88), 108-114. doi: $10.32718 /$ nvlvet8820.

Lavryshyn, Y. Y., Gutyj, B. V., Paziuk, I. S., Levkivska, N. D., Romanovych, M. S., Drach, M. P., \& Lisnyak, O. I. (2019). The effect of cadmium loading on the activity of the enzyme link of the glutathione system of bull organism. Scientific Messenger of Lviv National University of Veterinary Medicine and Biotechnologies. Series: Veterinary sciences, 21(95), 107-111. doi: $10.32718 /$ nvlvet9520.

López Alonso, M., \& Benedit, J. L. (2002). Interactions Between Toxic and Essential Trace Metals in Cattle from a Region with Low Levels of Pollution. Archives of Environmental Contamination and Toxicology, 42(2), 165-172. doi: 10.1007/s00244-001-0012-7.

Marushko, Yu. V., Tarynska, O. L., Olefir, T. I., Fus, S. V. (2010). Kadmii: nakopychennia ta vplyv na orhanizm dytyny. Medychna nauka Ukrainy, 3, 62-67. URL: http://nbuv.gov.ua/UJRN/nvnmu 2010 312 (in Ukrainian).

Myslyva, T. M. (2013). Svynets i kadmii u hruntakh ahrolandshaftiv Zhytomyrskoho Polissia. Visnyk Sumskoho natsionalnoho ahrarnoho universytetu. Seriia: Ahronomiia i biolohiia, 3, 43-50. URL: http://nbuv.gov.ua/UJRN/Vsna_agro_2013 3 _ 13 (in Ukrainian).

Myslyva, T. M. (2013). Svynets i kadmii u hruntakh pryrodnykh i ahrolandshaftiv Zhytomyrskoho Polissia. Visnyk Zhytomyrskoho natsionalnoho ahroekolohich- noho universytetu, 1(1), 36-49. URL: http://nbuv.gov.ua/UJRN/Vzhnau 2013 1(1) 8 (in Ukrainian).

Ostapyuk, A. Y., \& Gutyj, B. V. (2018). Influence of cadmium loading on morphological parameters of blood of the Laying Hens. Scientific Messenger of Lviv National University of Veterinary Medicine and Biotechnologies. Series: Veterinary sciences, 20(88), 48-52. doi: 10.32718/nvlvet8808.

Ostapyuk, A. Y., \& Gutyj, B. V. (2019). Influence of cadmium sulfate at different doses on the functional state of the liver of laying chicken. Scientific Messenger of Lviv National University of Veterinary Medicine and Biotechnologies. Series: Veterinary sciences, 21(94), 103-108. doi: 10.32718/nvlvet9419.

Petrynych, V. V., Vlasyk, L. I., \& Petrynych, O. A. (2017). Svynets: toksykolohichni, hihiienichni ta biolohichni aspekty. Klinichna ta eksperymentalna patolohiia, 16(2), 97-102. URL: http://nbuv.gov.ua/UJRN/ kep_2017_16_2_22 (in Ukrainian).

Slobodian, S. O., Gutyj, B. V., \& Leskiv, K. Y. (2019). The level of lipid peroxidation products in the rats blood under prolonged cadmium and lead loading. Ukrainian Journal of Veterinary and Agricultural Sciences, 2(3), 15-18. doi: 10.32718/ujvas2-3.04.

Slobodian, S. O., Gutyj, B. V., \& Murska, S. D. (2020). Effect of sodium selenite and feed additive "Metisevit plus" on morphological parameters of blood of rats at the intoxication of Cadmium and Lead. Scientific Messenger of Lviv National University of Veterinary Medicine and Biotechnologies. Series: Veterinary sciences, 22(97), 52-57. doi: 10.32718/nvlvet9710.

Stepanchuk, V. V. (2014). Ontohenetychni osoblyvosti tsyrkadiannykh khronorytmiv vilnoradykalnoho homeostazu za umov svyntsevoho otruiennia. Klinichna ta eksperymentalna patolohiia, 13(2), 131-133. URL: http://nbuv.gov.ua/UJRN/kep $2014 \quad 132233$ (in Ukrainian)

Vlizlo, V. V., Fedoruk, R. S., \& Ratych, I. B. (2012). Laboratorni metody doslidzhen u biolohii, tvarynnytstvi ta veterynarnii medytsyni. Dovidnyk. za red. Vlizla, V.V. Lviv. SPOLOM (in Ukrainian). 